\title{
Check List De Couto: Simplified Evaluation Of The Biomechanical Factor In A Hospital Institution Located In Vale Do Paraíba.
}

\author{
${ }^{1}$ Natália Lemes Siqueira Aguiar de Souza, ${ }^{1}$ Lariane Stefani do Nascimento \\ Oliveira, ${ }^{1,2}$ Claudia Lysia de Oliveira Araújo \\ ${ }^{1}$ Graduanda em Enfermagem pelo Centro Universitário Teresa D'Ávila- UNIFATEA, Lorena, SP, Brazil \\ ${ }^{2}$ Docente do PPG em Design Tecnologia e Inovação, UNIFATEA, LORENA, SP, Brazil
}

\begin{abstract}
A study with a quantitative and descriptive approach, aiming at characterizing the sociodemographic profile of nursing professionals of a given hospital institution, identifying the frequency of attrition in the workplace that each employee attributes in relation to their activities, assessing the degree of distribution of Discomfort in the body indicated by the participating employees and apply the simplified assessment of the biomechanical factor in the risk for musculoskeletal disorders of work-related upper limbs through the application of Couto's Checklist. The population was composed of 100 employees of the Institution in the position of nurse, nursing technician and nursing assistant. In the data collection, two questionnaires were used, the first containing questions regarding the socio-demographic data of each participant and also with questions related to the frequency of wear and discomfort in the body. The second questionnaire was a validated data collection instrument, entitled Checklist de Couto, a simplified biomechanical factor assessment for the risk of work-related upper limb musculoskeletal disorders. With the results we detected a very significant biomechanical factor. Where these factors indicate that the biomechanical risk of musculoskeletal injuries in employees is high, having as the major cause of this risk factor the excess of repetitions of the same work throughout the journey. This is due to poor physical positioning of the professionals when performing their work activities, generating a physical wear and tear such as pain in the hands and spine. It should be stressed that with the results obtained in the realization of the research certainly reinforced the need to implement standard precautionary measures and specific for the professionals' performance and health education in order to improve quality.
\end{abstract}

Keywords: nursing; ergonomics; worker health; tool.

\section{Introduction}

The worker, when performing his work activities, is exposed to different types of loads, mostly unhealthy, causing damages to his health. Faced with inadequate working conditions related to biological, physical, chemical, psychosocial and ergonomic factors, which can cause damage to the health of professionals working in hospitals in many countries, the International Labor Organization, since the 1980s. Of 40, has considered the problem as a topic of discussion and has made recommendations regarding hygiene and safety in order to adapt the working conditions of these professionals ${ }^{[1]}$.

Nursing professionals deserve special attention in regard to occupational health, because it is a class that performs its functions at an intense pace and suffers from a shortage of human resources and materials, generating accumulation of functions which ends up having physical repercussions and psychic for this worker

Employees end up being subjected to different workloads resulting from conditions that generate risks and end up causing wear (illness), consequently the life, health and assistance of the nursing professional are compromised. The pain and discomfort resulting from the performance of occupational activities are indicators of the risks used to detect possible problems in the body of the workers, and can also be understood as warning signs for future health problems ${ }^{[3]}$.

Among these loads we have the ergonomic factors that help to improve the work, preventing employees from exposure to risks. Ergonomics is the adaptation of the work according to the characteristics of the individuals thus promoting greater comfort and better performance of their work activities. Ergonomics was created in World War II with the aim of adjusting the worker's abilities in an unfavorable working environment, whose main objective is to promote worker safety, comfort and efficiency ${ }^{[4]}$.

The central focus of ergonomics is the relation of man to working conditions, from his posture and body movements (sitting, standing, static and dynamic, in effort or not), environmental factors (noise, vibration, lighting, Climate and chemical agents), equipment, control systems, positions and tasks performed ${ }^{[5]}$. 
Nursing represents the largest professional contingent of the hospital institutions, being considered a stressful profession, consequently, this professional develops and / or enhances their skills in a work environment permeated by stressors, which can directly reflect on their health, triggering disorders of All nature, in front of this a disease that is becoming more and more frequent are repetitive strain and work-related osteomuscular diseases ${ }^{[6] .}$

These are functional and / or organic disturbances that appear in the most diverse occupations and are therefore a cause for concern, as it causes great problems not only for the employee who may have temporary or permanent incapacity, but also for the institutions that suffer from absenteeism Which results in loss of productivity and quality of work performed, are more frequently induced by neuromuscular fatigue caused by work performed in a fixed position, ie, static work, with repetitive movements, especially of upper limbs. The clinical picture of LER / DORT is very varied and includes complaints of pain, tingling, numbness, shock, weight and early fatigue ${ }^{[7] .}$

A healthy and satisfied employee with his environment performs his functions with more quality, thus offering better care and care to his patients and consequently generating gains to his employer, in front of this the use of preventive actions, to make appropriate to the working conditions of the nursing professionals Collaborates to reduce illness through the quality of life in the workplace, providing conditions that motivate workers, such as work practice before, during and after their workday ${ }^{[8]}$.

Thus, Couto (a questionnaire based on the biomechanical factor in the risk for musculoskeletal disorders of the upper limbs) was used as one of the tools for this study, where the objective of the study was to characterize the socio-demographic profile of the professionals Of a particular hospital institution, identify the frequency of attrition in the workplace that each employee assigns in relation to their activities, assess the degree of discomfort distribution in the body indicated by the participating employees and apply the simplified assessment of the biomechanical factor in the risk For musculoskeletal disorders of work-related upper limbs through the application of Couto's Checklist.

\section{Method}

It is an exploratory descriptive study, transversal of quantitative nature. The present study was carried out in a large, non-profit, philanthropic General Hospital institution, being part of the network of hospitals providing services of the Unified Health System and also serving users of health care providers, Selfmanagement, health insurance and others, working with 184 beds, divided into 10 specialized sectors located in Vale do Paraíba-SP.

The study included nursing professionals regularly enrolled as employees of the institution, in the post of nurse, technician in nursing and auxiliary in nursing. The sample consisted of several age groups and both sexes. As inclusion criteria interviewees should be an employee of the institution, exercising the position in the nursing area, and agree to participate in the study signing the consent term. The exclusion criteria are: Not being an employee of the institution, obtaining another position in the same, disagreement in participating in the study.

The recommendations of Resolution No. 466/12, dated 12/12/2012, of the National Health Council were followed, and approval was obtained from the Committee of Ethics in Research of the University Center Teresa D'Ávila, opinion number 1.452.974, accordance with the required ethical and legal standards.

Participants were invited to participate after receiving all the clarifications about the research and after reading the Term of Free and Informed Consent, prepared according to resolution CNS 196/96. The confidentiality of the information was guaranteed to all; The guarantee of not having any sanctions or damages for the non participation or the desistence at any moment; The right to answers to doubts and the inexistence of any financial burden and / or remuneration to the participant. Data collection was performed in June and July 2016, through two structured questionnaires, one containing questions regarding the socio-demographic data of each participant and also with questions related to the frequency of wear and discomfort in the body. The second questionnaire was a validated data collection instrument, entitled Checklist de Couto, a simplified assessment of the biomechanical factor in the risk for musculoskeletal disorders of work-related upper limbs.

The data collected were entered electronically into a database in Excel Software, and the data collected through Couto's CheckList feature was entered into the Ergolandia 5.0 Software. The categorical variables were frequency, percentage and average in some cases. These data were presented below in tabular form, and in descriptive form, and are then also discussed based on the selected literature.

\section{Results And Discussion}

A total of 100 employees were interviewed, 91 (91\%) female and $9(9 \%)$ male, while 59 were married, $26(26 \%)$ were single, $11(11 \%)$ And four (4\%) widowers. Concerning the age group, the survey revealed that $35(35 \%)$ of employees are between 40 and 49 years of age, $31(31 \%)$ are between 30 years. 
Table 1- Distribution of the participating employees $(\mathrm{N}=100)$ according to Demographic Partner data. Vale do Paraíba, São Paulo, 2016.

\begin{tabular}{|l|c|c|}
\hline Variables & \multicolumn{2}{|c|}{ Employees Participants } \\
\hline Sex & $\mathbf{N}$ & $\mathbf{\%}$ \\
\hline Female & 91 & $91 \%$ \\
\hline Male & 9 & $9 \%$ \\
\hline Marital Status & & $26 \%$ \\
\hline Not Marriet & 26 & $59 \%$ \\
\hline Marriet & 59 & $4 \%$ \\
\hline Widower & 4 & $11 \%$ \\
\hline Separate & 11 & \\
\hline
\end{tabular}

\begin{tabular}{|c|c|c|}
\hline Age Group & & $25 \%$ \\
\hline $\mathbf{2 0 - 2 9}$ & 25 & $31 \%$ \\
\hline $\mathbf{3 0 - 3 9}$ & 31 & $35 \%$ \\
\hline $40-49$ & 35 & $9 \%$ \\
\hline 50 or more & 9 & $19 \%$ \\
\hline Professional Category & & $78 \%$ \\
\hline Nurse & 19 & $3 \%$ \\
\hline Nursing technician & 78 & \\
\hline Nursing assistant & 3 & \\
\hline
\end{tabular}

Source: Authors, 2016.

According to data from the socio-demographic profile of nurses, it was found in this study that this majority of female nurses is due to the rise of women in society and in the labor market, often performing the function of Head of the family, thereby gaining space and recognition in both the public and private spheres [9]. The identification of the sociodemographic profile of a particular clientele, may direct care and actions according to the profile of the patient present in the study [10]. Currently the health workforce is female, representing about $70 \%$ of the contingent, this only tends to grow in the coming years, demonstrating that feminization is a strong characteristic of the sector, but the number of men in nursing has also been growing significantly ${ }^{[11]}$. The law that regulates nursing as a professional category that differs in its attributions is to $7,498.86$ by decree $94,406.87$, reaffirming the existence of nursing professionals who work in three different categories: the nurse, the nursing technician and nursing assistant. The factor that interferes in order for this professional to fit into one of these categories is the level of training, where the nurse has training at a higher level, being able to participate in and perform activities of high complexity, Has the right to perform tasks of medium complexity determined by the nurse, the nursing assistant is a category that was responsible for the care that aim to guarantee comfort and well-being of the patient through routine activities that To be carried out require a basic knowledge acquired through a basic technical level training course ${ }^{[12] .}$ The hospital institutions work from their contingent, which consists mostly of the nursing team, a professional category that has been facing changes resulting from the replacement of nursing assistants by nursing technicians, a fact that is occurring because the nursing assistant can only provide Nursing care, take care of their hygiene, care for and observe this patient, in front of this for hospital institutions to have a human resource fully formed by nursing technicians and nurses will bring more benefits because of the level of care that can be provided and offered By these professionals ${ }^{[13]}$. In the hospital scope the activities developed by the nursing team have as main focus the care, management, attendance, administration and teaching. However, there is a hierarchical level that is respected according to the level of assistance promoted by the team, where the nurse acts in the management of his unit and team, being responsible for the more complex care, since the technicians perform their functions at less complex levels ${ }^{[14]}$. Table 2 shows the distribution of the frequency of wear at the workplace that each employee attributes in relation to their activities.

Table 2- Distribution of participating employees $(\mathrm{N}=100)$ according to frequency of attrition at work. Vale do Paraíba, São Paulo, 2016.

\begin{tabular}{|l|c|c|}
\hline Variables & \multicolumn{2}{|c|}{ Employees Participants } \\
\hline & $\mathbf{N}$ & $\mathbf{\%}$ \\
\hline Never & 4 & $4 \%$ \\
\hline A few times a year & 7 & $7 \%$ \\
\hline A few times a month & 17 & $17 \%$ \\
\hline Sometimes in the week & 30 & $30 \%$ \\
\hline Daily & 42 & $42 \%$ \\
\hline
\end{tabular}

Source: The authors, 2016. 
The variables according to the frequency of attrition mentioned by the employees interviewed, 42 (42\%) attributed daily wear to their hospital activities, 30 (30\%) attributed wear at times in the week, 17 (17\%) attributed wear at times Seven (7\%) attributed wear at a few times per year, while four (4\%) reported that their activity in the hospital environment never brings a feeling of wear and tear.

Stress in the nursing area in professionals who work more than 15 years in office and have low social support have a higher chance of high wear. Being a coach / helper also results in a greater chance of being in the passive work quadrant. These quadrants are those with the highest risk for illness ${ }^{[15]}$.

It is important to note that other situations may also be influencing this result of daily wear and tear. One of them concerns the demographic characteristics of the participating employees. Health professionals, although young, have professional experience and have been in the hospital sector for quite some time. Professionals of the health area with more professional experience have lower levels of frequency of wear ${ }^{[16] .}$

One of the factors that may be related to and directly influence the physical and psychological attrition of the health worker is the aspects of the organization of their work. Besides the professional of nursing to live daily with the pain and the suffering of its patients, as well as becomes confidant of them when being present in the moment in which they need to express some intimate question and with this ends up causing in a daily and frequent wear to that worker, Where they are at high risk of collapsing ${ }^{[15-17]}$.

The nursing worker can often feel fragile and consequently unable to fully perform their duties. Because it is a professional who is constantly dedicated to the care provided to his patients, being subject to illness and collapse, including Burnout syndrome, and can affect the professional with emotional and physical manifestations. Faced with this all these factors are putting at risk the health of the workers and with this bringing consequences in their performance of their professional activities and may even reach the absenteeism of this employee ${ }^{[18-19]}$.

Frame 1 shows the distribution of the discomfort sites indicated by the participating employees.

Frame 1- Distribution of discomfort indicated by the participating employees $(\mathrm{N}=100)$. Vale do Paraíba, São Paulo, 2016.

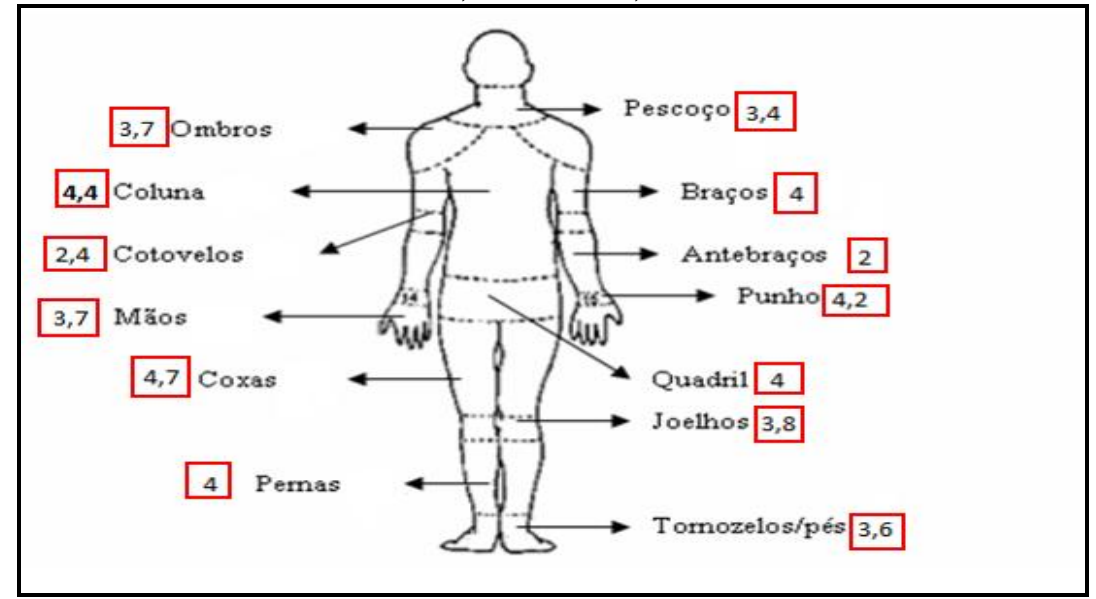

Source: The authors, 2016.

In the data collection, we used Table 1, the data obtained were inserted, electronically, into a database built by the researchers themselves, in the Excel Software, where at the end of the summation the total average for each region of discomfort was then calculated and then demonstrated In the table above.

The mean of the results showed that the thighs were the site of greatest discomfort mentioned by the participants, representing a total of (4.7), followed by the column with a total of (4.4), Arms and legs four (4), knees $(3,8)$, hands and shoulders with $(3,7)$, ankles / feet $(3,6)$, neck $(3,4)$, elbows $(2,4)$ And finally forearms representing two (2).

One of the tools used was Couto's (1995) checklist, it is composed of 25 questions related to the characteristics of the work such as physical overload, hand applied force levels, posture at work, work station and static effort, The repetitiveness and organization of work, and finally the evaluation of the work tools. For each question the respondent had to assign YES or NO as a response, and the answers that imply ergonomic risks to the workers are assigned a point to the total score. Afterwards, scores were scored based on the assignment of points and, from there, biomechanical risk could be interpreted, Table 3 . 
Table 3 - Interpretation of Couto's Checklist

\begin{tabular}{|c|c|}
\hline Score (Points) & Ergonomic risk level \\
\hline From 0 to 6 points & No risk \\
\hline Between 7 and 9 points & Risk Unlikely, but possible \\
\hline Between 10 and 14 points & Risk \\
\hline 15 or more points & High Risk \\
\hline
\end{tabular}

Source: Software Ergolândia, 2015.

Regarding the Interpretation of Couto's Checklist the results were presented in Table 4.

Table 4- Distribution of participating employees $(\mathrm{N}=100)$ according to Couto's Checklist Interpretation. Vale do Paraíba, São Paulo, 2016.

\begin{tabular}{|l|c|c|}
\hline Variables & \multicolumn{2}{|c|}{ Employees Participants } \\
\hline No risk & N & \% \\
\hline From 0 to 6 points & & $8 \%$ \\
\hline Risk Unlikely, but possible & 16 & $16 \%$ \\
\hline Between 7 and 9 points & & $37 \%$ \\
\hline Risk & 37 & \\
\hline Between 10 and 14 points & & $39 \%$ \\
\hline High Risk & 39 & \\
\hline 15 or more points & & \\
\hline
\end{tabular}

Source: The authors, 2016.

Through the ergonomic analysis of the sectors in which the employees studied, it is possible to note the need to suggest changes in the work stations in order to minimize the risk factors for DORT and to improve the quality of life of employees. Considering that DORTs have a considerable impact on workers' lives and have a significant socioeconomic repercussion ${ }^{[20]}$.

Inappropriate use of the upper limbs is the major cause of injury to the shoulders and hands. The development of painful and inflammatory disorders is almost always related to postural factors (hand and wrist position, for example), fixation of postures for prolonged periods in isometry, wrist deviations, movement of tweezers with hands, Shoulder elevation, tensioned arms, plus the combination of high forces and high repetitiveness. In addition to these, it is already well described in the literature the negative action of stress in the development of DORT's [21].

\section{Conclusion}

The results obtained through the perception of the 100 employees of the different sectors of the health institution show the importance of the study of applied ergonomics using the Couto check list method as a tool, we detected a significant biomechanical factor, that is, a high biomechanical risk index to occur Muscle skeletal injuries in employees, having as the major cause of this risk factor the excess of repetitions of the same work throughout the day. This is due to poor physical positioning of the professionals when performing their work activities, generating a physical wear and tear such as pain in the hands and spine. It should be stressed that with the results obtained in the realization of the research certainly reinforced the need to implement standard precautionary measures and specific for the professionals' performance and health education in order to improve quality.

\section{References}

[1]. Moraes MGV. Doenças Ocupacionais Agentes: Físico, químico, biológico, ergonômico. São Paulo; 2013.

[2]. Pasa TS,Magnago TSBS, Silva RM, Cervo AS, Beck CLC, Vieiro NC. Riscos ergonômicos para trabalhadores de enfermagem ao movimentar e remover pacientes. Rev. Enf UFSM,2015; V.5 (1):92-102.

[3]. Felli V. Condições de trabalho de enfermagem e adoecimento: motivos para a redução da jornada de trabalho para 30 horas. Enf. Foco. 2012; V.3(4): 178-181.

[4]. Rocha G. Trabalho, saúde e ergonomia. Curitiba: Juruá; 2012.

[5]. Renner JS, Taschetto DVR, Baptista GL, Basso CR. Qualidade de vida e satisfação no trabalho: a percepção dos técnicos de enfermagem que atuam em ambiente hospitalar.Rev. Min Enferm, 2014; V.18 (2):440-446.

[6]. Sarturi F. Nível de stress do enfermeiro hospitalar frente a suas competências. 2009. Santa Maria- Dissertação de mestradoPrograma de Pós-Graduação em Enfermagem- Universidade Federal de Santa Maria.

[7]. Souza FKN, Ziviani FA. A qualidade de vida no trabalho correlacionada à prática da ginástica laboral. Rev. Cient, do Depart de Ciên Juríd, Polít e Geren do Uni-BH,2010; V.3 (1):1-27.

[8]. Carvalho MD, Oliveira IRS. Absenteísmo na enfermagem: levantamento das causas na literatura da área. 2011 [Capturado em 24 fev.2016] Disponível em https://www.posgraduacaoredentor.com.br/hide/path_img/conteudo_5423440bca897.pdf 
[9]. Corrêa ACP, Araújo EF, Ribeiro AC, Pedrosa ICF. Perfil sociodemográfico e profissional dos enfermeiros da atenção básica á saúde de Cuiabá- Mato Grosso. Rev. Eletr. Enf. 2012, V.1 (14): 171-180. [capturado em 12 de junho de 2016] Disponível em: https://www.fen.ufg.br/fen_revista/v14/n1/pdf/v14n1a20.pdf.

[10]. Gautério DP, Santos SSC, Silva BT,Cruz VD, Zortea B, Alves I. J Nurs Health. 2013; 3(2): 182-94.

[11]. Ribeiro AC, Ramos LD, Mandú ENT. Perfil sociodemográfico e profissional de enfermeiros de um hospital público de Cuiabá-MT. Cien. Cuid. Saúd, 2014; V.13(4):625-633.

[12]. Pinto BMS, Barbosa DAS, Carvalho J, Thomas MCA, Arçari DP. O enfermeiro, o técnico e o auxiliar de enfermagem sob a óptica dos acadêmicos. São Paulo; 2011

[13]. Leite MT, Gonçalves LHT, Battisti IDE, Hildebrandt LM. Recursos humanos de enfermagem: formação e atualização na área do envelhecimento. Rev. Rene, 2011; 12(1):24-32.

[14]. Nascimento SM. As funções gerenciais do enfermeiro no cotidiano da assistência hospitalar. Rio de Janeiro, 2013. Dissertação (Mestrado) - Curso de Enfermagem, Universidade Federal do Estado do Rio de Janeiro- UNIRIO.

[15]. Urbanetto JS, Silva PC,Hoffmeister E, Negri BS,Costa BEP,Figueiredo CEP. Rev. Latino-am. Enfermagem Artigo,2011; V.5 (19):2-12.

[16]. Lacruz SP, Abellán MV. Desgaste profissional, stress e satisfação no trabalho do pessoal de enfermagem em um hospital universitário. Rev. Latino-am. Enfermagem, 2015; V.3 (13):543-552.

[17]. Kovacs MJ. Sofrimento da equipe de saúde no contexto hospitalar: cuidando do cuidador profissional. Mund.Saúde,2010; V.34 (4):420-429 [Capturado em 23 de jan.2016] Disponível em http://www.saocamilo-sp.br/pdf/mundo_saude/79/420.pdf.

[18]. Prudente JAB. O desgaste de trabalhadores de enfermagem no cuidado a pacientes onco-hematológicos hospitalizados: Causas e estratégias de minimização. Florianópolis, 2014. Dissertação (Mestrado) - Curso de Gestão do Cuidado em Saúde e Enfermagem, Universidade Federal de Santa Catarina.

[19]. 19. Cimiotti JP, Aiken LH. Burnout. Gestão em enfermagem: ferramenta para a prática segura. São Paulo: Yendis; 2011.

[20]. Ferreira VMV, Shimano SGN, Fonseca MC. Registro. Fisioterapia na avaliação e prevenção de riscos ergonômicos em trabalhadores de um setor financeiro. Rev. Fisio. Pesq. 2009; V.16 (3): 239-245.

[21]. Trindade JLA. Biossegurança e os riscos ergonômicos em relação a mecânica corporal do profissional de saúde. Rev. Univ.Luter do Brasil, 2011, V.4 (5): 124-139. 